\section{International Scientific Journal Theoretical \& Applied Science}

Otabek Muhammadievich G`aybullaev The Samarqand State University Chief of Department

Doctor of science, Professor Samarqand, Uzbekistan

p-ISSN: 2308-4944 (print) e-ISSN: 2409-0085 (online)

Year: 2017 Issue: 04 Volume: 48

Published: $30.04 .2017 \quad \underline{\text { http://T-Science.org }}$

SECTION 30. Philosophy

\title{
SOME ASPECTS AND HISTORICAL FACTORS OF INTEGRATION PROCESSES IN SPHERE OF GLOBALIZATION OF THE ECOLOGICAL POLICY
}

Abstract: Given article is devoted disclosing of defining factors of the majority of the integration processes, concerning spheres of globalization of an ecological policy. Stages of formation of the international ecological policy, a direction, forms and principles of the international cooperation in ecology sphere, the international agreements in the field of preservation of the environment, concern them first of all.

Key words: globalization, ecology, economy, society, ecological policy, integration processes.

Language: English

Citation: G`aybullaev OM (2017) SOME ASPECTS AND HISTORICAL FACTORS OF INTEGRATION PROCESSES IN SPHERE OF GLOBALIZATION OF THE ECOLOGICAL POLICY. ISJ Theoretical \& Applied Science, 04 (48): 83-86.

Soi: http://s-o-i.org/1.1/TAS-04-48-14 Doi: crossef https://dx.doi.org/10.15863/TAS.2017.04.48.14

\section{Introduction}

Global character of ecological crisis causes necessity of realization of the international ecological activity. In development of the international cooperation in the field of environment protection it is possible to allocate some stages:

1. 60-70th years of the $\mathrm{XX}^{\text {th }}$ century - it is connected with formation of system of the international nature protection cooperation.

2. 80-90th years of the $\mathrm{XX}^{\text {th }}$ century - has marked itself the beginning of working out and realization of Strategy of a Sustainable Development.

3. 1995-on the present - it is connected with realization of a Sustainable Development and cooperation of the international nature protection activity of the states.

Let's consider the basic achievements and lacks of the first period of the international ecological cooperation.

Local character of the agreements mentioning only separate aspects of global problems became characteristic feature of the first stage of the international ecological integration. In 50-60th years some forums and the conferences devoted to preservation of the environment have been spent, and a number of agreements of local type is signed. The resolution of XVII Session of General Assembly of the United Nations Organization, accepted in 1962 became one of the first documents of global importance. There has been noticed that economic development and wildlife management should be synchronous and pass under the control of the international public organizations in it.

\section{Materials and Methods}

In 1968 intergovernmental conference on problems of biosphere with participation of UNESCO, the World Association of Public Health Service, the International Union of Wildlife Management where for the first time have been considered scientific principles of wildlife management and protection of natural resources has taken place. Since 1970 has began to be realized under the aegis of UNESCO the long-term program of preservation of the nature "The Human and the Biosphere".

Bases of an ecological policy of the modern state have been put in 1971 on the international symposium in the Swiss city of Fune. Acceptance in 1972 of the Stockholm declaration at the Conference of the United Nations on environment became the turning point of the first period. It has been proclaimed, that "... preservation and improvement of quality of environment surrounding the person is the important problem influencing on well-being of the people..." Also it has been recognized, that "the person has a fundamental law on freedom, equality 
and favorable living conditions in the environment which quality allows conducting a worthy and prospering life, and bears the main responsibility for protection and environment improvement for the blessing present and the future generations".

The human rights on favorable environment began to be fixed in new Constitutions of the countries accepted after 1972, and also in the general laws on protection of a surrounding environment. The declaration of principles accepted at the Stockholm conference, included 26 principles in relation to an environment problem. Among them human rights on favorable environment; preservation of natural resources for present and future generations; economic and social development; the sovereignty of the rights of the states on working out of own natural resources and responsibility of the states for a damage to environment; necessity of the joint decision of global problems and others. The plan of measures contained 109 points in sphere organizational, economic, political problems of preservation of the environment. The Stockholm declaration became the first large agreement considering problems of transboundary pollution. The basic export of an ecological damage had been declared those developed countries in which territory in areas of concentration of the industry high level of environmental contamination was observed. Under the conference decision has been formed UNPE (the United Nations Program on Environment) constantly operating body of the United Nations on preservation of the environment, Environment Fund, and on June, 5th it has been proclaimed as the World Day of Environment.

Following step became the signing of the Final certificate of Meeting on safety and cooperation in Europe in Helsinki in August, 1975 with participation of all European countries, the USA and Canada where along with political questions of ensuring of safety have been fixed questions of ecological safety, were defined the purposes, areas, forms and methods of the international ecological cooperation. Atmosphere pollution abatement, protection of waters has been carried to cooperation areas from pollution, protection of the sea environment, protection of soil, reserves, environment in cities. Among forms and methods of such cooperation were offered: information interchange, the organization of conferences, an exchange of scientific researchers.

Within the limits of realization of the Helsinki decisions by the countries-participants the Convention on transboundary pollution of atmospheric air (1979), the Convention on transboundary influence of industrial failures (1992) and others subsequently have been accepted. In 1982 at special session UNPE the Nairobi declaration which has confirmed principles of the Stockholm conference has been proclaimed.
The recognition of a priority of the joint decision of global problems became the basic achievement of the first stage of development of the international cooperation. However the basic efforts went on overcoming of consequences of deterioration of ecological conditions, instead of on elimination of the reasons. The majority of documents have not brought a significant positive effect because of considerable economic costs.

Working out of the global strategy directed on elimination of the reasons to degradation of an environment became the major problem for the second period.

The second stage covers the period 80-90th years of the $\mathrm{XX}^{\text {th }}$ century. For preparation of global nature protection strategy has been created the International Commission on Environment and Development (ICED), considered two approaches to the decision of problems of environment - traditional and alternative.

The first placed emphasis on environmental contamination problems (climate change, atmosphere pollution, a radioactive waste, potable water problems etc.); problems connected with natural resources (deforestification, desertification, an exhaustion of sea resources); problems of settlements of the human (land tenure, water supply, high rates of an urbanization). According to ICED, the traditional approach has led to considerable progress in the field of environment monitoring, to growth of ecological awareness of the public. However the undertaken nature protection activity was limited, as a rule, to the developed countries, disregarding problems of developing countries.

As a result, ICED has suggested using the alternative approach considering the general sources of environmental problems in following directions:

- Perspectives of demographic growth and economic development;

- Energy, environment and development (including ozone layer problems, air pollution, the acid rains, renewed resources, etc.);

- The industry, environment;

- Agriculture, environment and development;

- Global ecological monitoring.

The report "Our General Future" became a result of work ICED, in which the concept of steady social and economic development in balance with environment for the first time has been put forward.

On the basis of the Concept of the Sustainable Development the international cooperation in the field of ecology was carried out up to the end of XX century. Its ideas have laid down in a basis of variety of the international contracts and agreements. Among them the Viennese report 1986 on decrease in emissions of hydrocarbons and others polluters; the Montreal report on protection of an ozone layer of 1987; the Hague declaration of 1989 in which was underlined that global problems demand creation of 
the new organization in the United Nations allocated with the right to make of the decision even in the absence of unanimity and to impose penalties for infringement of the international agreements.

Sustainable Development principles have found reflexion in final documents of the international conference in Rio de Janeiro of 1992 which has marked itself end of working out of the Concept of the Sustainable Development. Conference has collected about 15 thousand delegates from 178 countries of the world. Its basic decisions became "The declaration of principles of a policy of preservation of the environment" and "The agenda The XXI ${ }^{\text {st }}$ century". The sustainable development has been defined as the process meeting requirements of the present, but not depriving future generations the possibility to satisfy its requirements.

In the United Nations the special Commission on a sustainable development has been created. "The agenda" included more than 100 programs on global problems and formulated the conditions necessary for a sustainable development of all countries. Besides, in Rio de Janeiro contracts about principles of protection and rational use of woods of all climatic zones have been concluded; the Convention on a climate; the Convention on protection of a biological variety and others. These documents reflected intentions of the state-participants to develop international ecological cooperation on the basis of sustainable development principles, however they did not contain any obligations.

In December, 1997 representatives of 159 states have gathered at the world ecological forum in Kyoto which were passing under the aegis of the United Nations. The Kyoto report has fixed obligations of the countries of the European Union to reduce the general emissions of polluting substances in environment on $8 \%$ in comparison with 1990 around 2008-2012. The USA has stipulated for themselves a boundary in $7 \%$, and Japan - in $6 \%$. Despite the ambiguity, the Kyoto report has been signed by 40 countries, but not all ratified it. Refusal of the countries to participate in the Kyoto agreement explain that benefits on prevention of climatic changes are expected only in long-term prospect, and costs become notable at once. Another argument is scientific uncertainty acts. Till now there is no common opinion, whether there is actually a global warming and how much it is caused by anthropogenous influences, including emissions in atmosphere of hotbed gases. Thereupon there is a question, how much are defensible economic expenses for the problem decision which scale of consequences else up to the end is not clear.

The Kyoto report has finished the second stage of the international ecological integration. For this period much has been reached in respect of comprehension of necessity of harmonization of economic growth and development of a surrounding environment. For rather short time the system of the international cooperation in the field of protection of the environment, focused on elimination of the reasons of deterioration of ecological conditions has been generated. It included cooperation within the limits of the international intergovernmental and non-governmental organizations; cooperation within the limits of multilateral and bilateral agreements. It is possible to consider as the main result is formation of the complete Concept of the Sustainable Development.

At the same time it is obvious that notable positive results of ecological integration following the results of two periods has not followed. There was a necessity of search of new ways of the decision of global environmental problems.

At the present stage of the international cooperation in ecology sphere interstate cooperation continues to develop actively. By this time is over 1600 multilateral conventions and agreements and over 3000 bilateral contracts, partially or completely devoted to environment protection.

\section{Conclusion}

There are a lot of problems. In the majority they rest in finance expenses. Market mechanisms are realized in insufficient degree (questions of payment for environmental contamination are not solved), financing of numerous ecological programs and projects frequently appears under the threat. At the present stage it is possible to consider as success increase in quantity of the countries which have signed the Kyoto report (among them and Russia). However it cannot be considered effective, yet do not ratify all developed countries, first of all the USA. At the same time at all ambiguity of the Kyoto report it has executed the paramount role, having brought on the agenda an attention to the question on necessity of reduction of negative ecological consequences from economic activities and have been stimulate working out of is standard-legal tools and introduction of market mechanisms in ecological sphere. 


\begin{tabular}{l|lrl|l|ll} 
& ISRA (India) & $=\mathbf{1 . 3 4 4}$ & SIS (USA) & $=\mathbf{0 . 9 1 2}$ & ICV (Poland) & $=\mathbf{6 . 6 3 0}$ \\
Impact Factor: & ISI (Dubai, UAE) $=\mathbf{0 . 8 2 9}$ & PUHL (Russia) $=\mathbf{0 . 2 3 4}$ & PIF (India) & $=\mathbf{1 . 9 4 0}$ \\
& GIF (Australia) & $\mathbf{0 . 5 6 4}$ & ESJI (KZ) & $=3.860$ & IBI (India) & $=\mathbf{4 . 2 6 0}$ \\
& JIF & $\mathbf{1 . 5 0 0}$ & SJIF (Morocco) & $=\mathbf{2 . 0 3 1}$ & & \\
\hline
\end{tabular}

\section{References:}

1. Nikanorov AM (2000) Global'naya ekologiya / A.M. Nikanorov, T.A. Horuzhaya. -M., 2000. $284 \mathrm{p}$.

2. (2003) Ekologicheskaya politika / [pod red. S.V. Ustinkina]. - N. Novgorod, 2003. - $151 \mathrm{~s}$.

3. Ekologiya / [pod red. S.A. Bogolyubova]. - M., 2002. - 286 p.

4. (2004) Ekologiya / [pod red. V.V. Denisova]. Rostov n/D. - 2004. - 671 p.

5. (2005) Ekologicheskoe pravo / [pod red. O.L. Dubovika]. - M., 2005. - 767 p.

6. Ivanova AL (2003) Pravo ES ob obrashchenii s othodami / A.L. Ivanova // YUridicheskiy mir. - 2003. - № 9. - p. 35-48.

7. Lopashin VN (2004) Ekologicheskaya bezopasnost': problemy konstitucionnoy zakonnosti / V.N. Lopashin // Gosudarstvo i pravo. -2004 . - № 2. - p. 21-31.
8. (1995) Obzor zakonodatel'stva gosudarstvchlenov SNG i stran Baltii : Voprosy sotrudnichestva v oblasti ohrany okruzhayushchey sredy // Zakonodatel'stvo i ekonomika. - M., 1995. - Vyp. 21/22. - p. 157159.

9. Petrova TV (2000) Ekonomicheskiy mekhanizm realizacii ekologo-pravovyh norm / T.V. Petrova. - M., 2000. - 64 p.

10. Rengeling GV (2003) Evropeyskiy kodeks okruzhayushchey sredy: utopiya ili deystvitel'nost'? / G.V. Rengeling // Ekologicheskoe pravo. - 2003. - № 3. - p. 3435.

11. Tret'yakova AA (2003) Ekologicheskie prava grazhdan po zakonodatel'stvu gosudarstvchlenov Evropeyskogo soyuza. - M., 2003. $207 \mathrm{p}$. 